American Birding Association, Monographs in Field Ornithology No. 2.

11. Sadler, T.S. and M.T. Myers. 1976. Alberta birds 1961-1970. Provincial Museum of Alberta Natural History Section Occasional Paper No. 1. Edmonton, Alberta.

12. Smith, A. 1996. Atlas of Saskatchewan Birds. Special Publication No. 22. Saskatchewan Natural History Society, Regina, Saskatchewan.

13. Soucy, L.J. Jr. 1980. Three long distance recoveries of banded New Jersey barn owls. North American Bird Bander 5: 97.

14. Soucy, L.J. Jr. 1985. Bermuda recovery of a common barn-owl banded in New Jersey. Journal of Field Ornithology 56: 274.
15. Stewart, P.A. 1952. Dispersal, breeding behavior, and longevity of banded barn owls in North America. Auk 69: 227-245.

\section{Acknowledgements}

The authors would like to thank Lynn Vogt (Calgary Field Naturalists), Mark Heckbert (Alberta Environment-High Prairie), and Denver Holt (Owl Research Institute, Montana) for providing information on previous records in and outside the province. Also thanks to Dr. Ken Schmidt for bringing the Bashaw record to our attention, and to Dan Lockshaw for providing the North America range map of the Barn Owl from his website. Finally, thank you to Jocelyn Hudon (Curator of Ornithology, Provincial Museum of Alberta) for providing the museum accession numbers.

\title{
LOGGERHEAD SHRIKE LARDER AND PREY
}

BRIAN JOHNS, Canadian Wildlife Service, 115 Perimeter Road, Saskatoon, SK S7N OX4 and DAVID JOHNS, 51 Beurling Crescent, Saskatoon, SK S7H 4V6

While conducting a Loggerhead Shrike survey near Kenaston, Saskatchewan on June 28, 2000, we observed a single adult shrike perched on an overhead wire about 50 metres from a clump of Thorny Buffaloberry (Shepherdia argentea) (Figure 1). We searched the buffaloberry clump for a nest and discovered three recently fledged young and an empty nest. The remains of a fourth young were discovered in a coyote regurgitate on the nearby road. The young were estimated to be about 18-19 days of age; they could not fly, but fluttered and hopped on the ground and climbed to the top of a large buffaloberry clump. The nest was $90 \mathrm{~cm}$ above the ground in the crotch of several buffaloberry branches. While we searched the area, the second adult came nearby and scolded us.

The buffaloberry clump was in a roadside ditch adjacent to a 3 -strand 


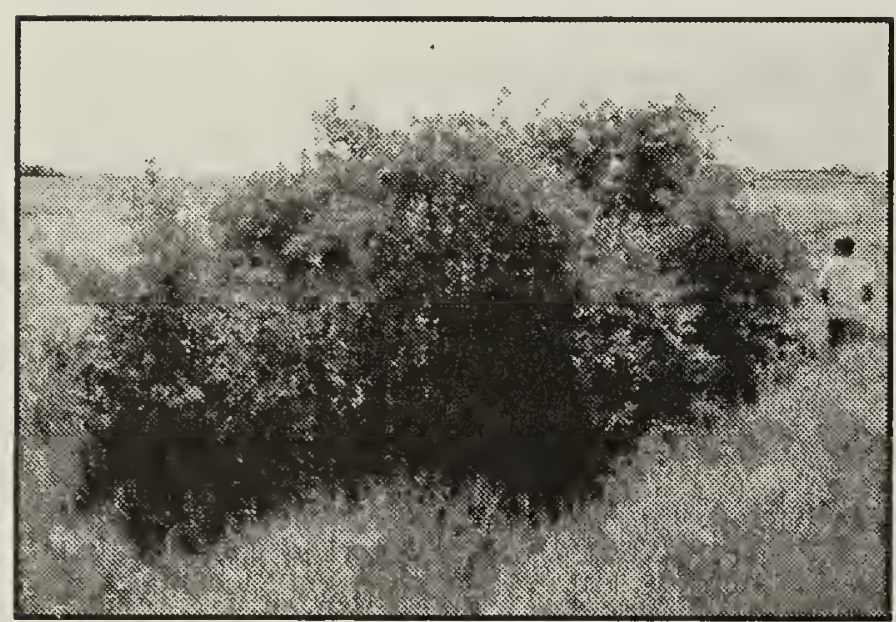

Figure 1. Nest Shrub with David Johns.

Brian Johns

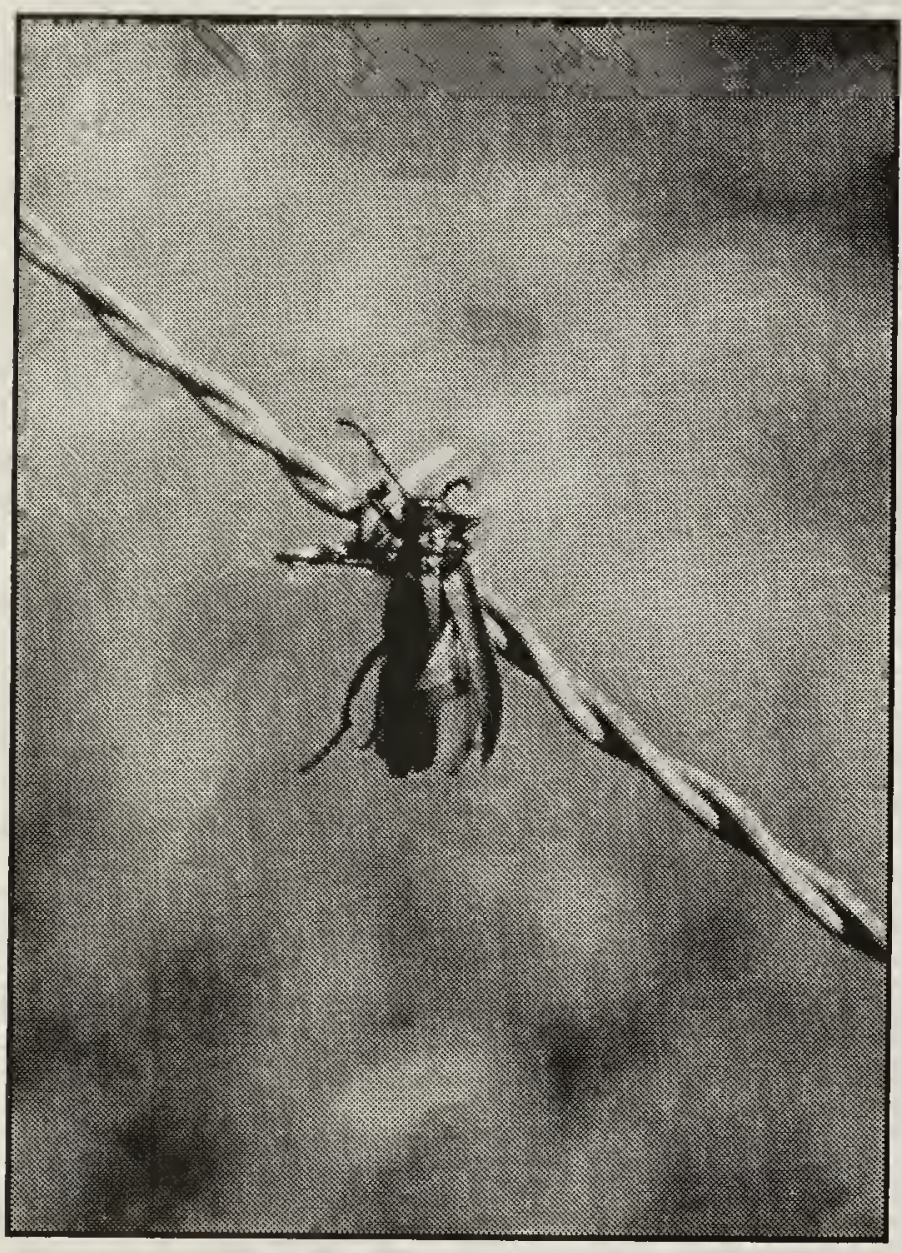

Figure 2. Impaled Nuttall's Blister Beetle. Brian Johns

barbed wire fence that enclosed an ungrazed pasture, former cropland, and a dry wetland. We located the following items impaled on the barbs of the fence : 57 frogs and 1 Nuttall's Blister Beetle (Lytta nuttalli) (Figure 2.). In the buffaloberry clump, we located another four frogs impaled on buffaloberry thorns. Several of the frogs showed signs of having been fed upon, while others were whole. The frogs were impaled either through the head or the body (Figure 3 ). The body length

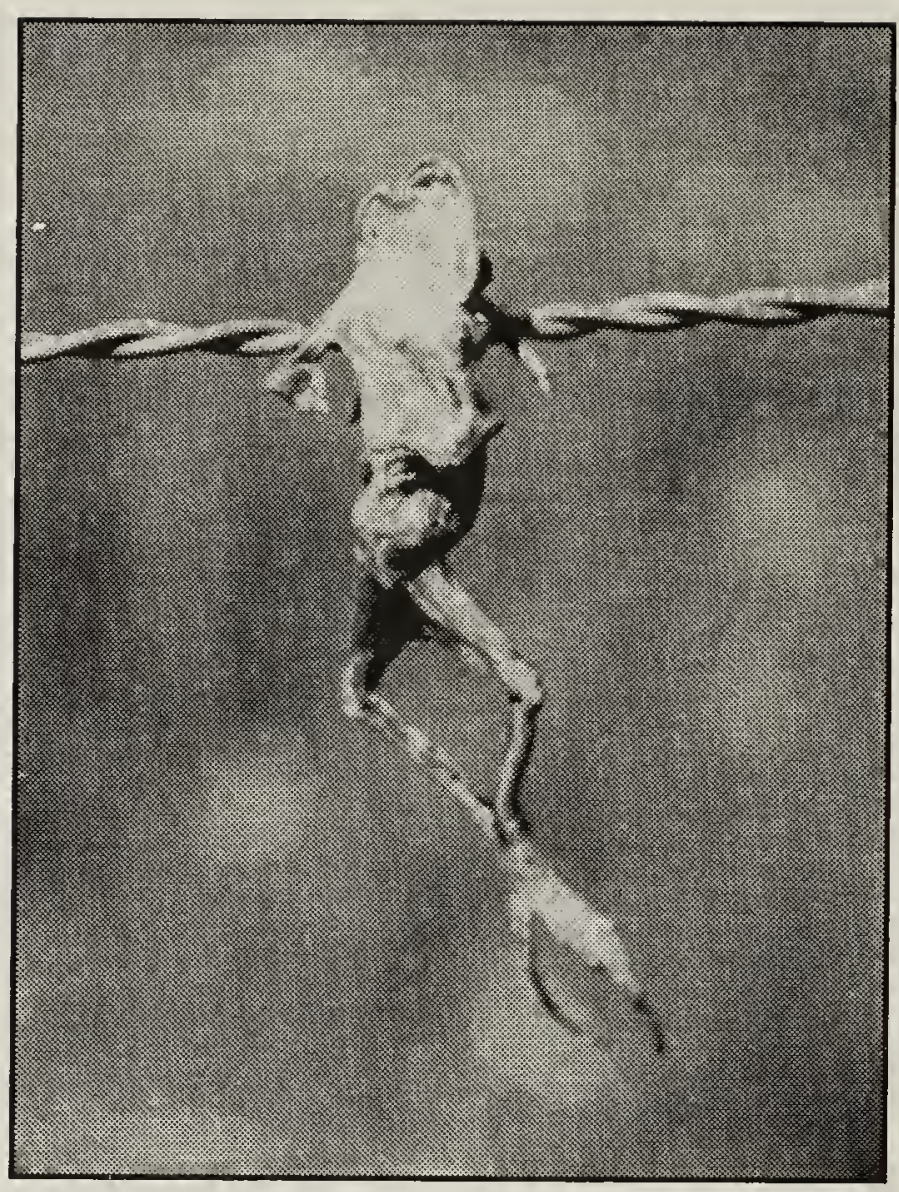

Figure 3. Impaled Wood Frog. Brian Johns

(excluding hind legs) ranged from 25 $\mathrm{mm}$ to $45 \mathrm{~mm}$ in size. We collected a 32 $\mathrm{mm}$ long frog that was later identified as a Wood Frog (Rana sylvatica).

On July 12 , we revisited the area and observed two adult shrikes and two young near the nest shrubs. We searched the fence west of the location searched on 28 June and discovered the following additional items impaled on barbs: 1 Wood Frog, 19 Nuttall's Blister Beetles and 1 Red Milkweed Beetle (Tetraopes tetraophthalmus). At this time we captured one of the adult shrikes and banded it with a USFWS band (8051-97037) on the right leg and a yellow band on the left.

The length of fence used for the larder totaled $455 \mathrm{~m}: 150 \mathrm{~m}$ east, $255 \mathrm{~m}$ west and $50 \mathrm{~m}$ south of the nest site (Figure 4). The frogs were spread out over 335 $\mathrm{m}$ of the east/west fence while the blister beetles were concentrated between 180 and 200 metres west of the nest. In Saskatchewan, blister beetles are 
Figure 4. Schematic of Loggerhead Shrike larder, Kenaston SK.

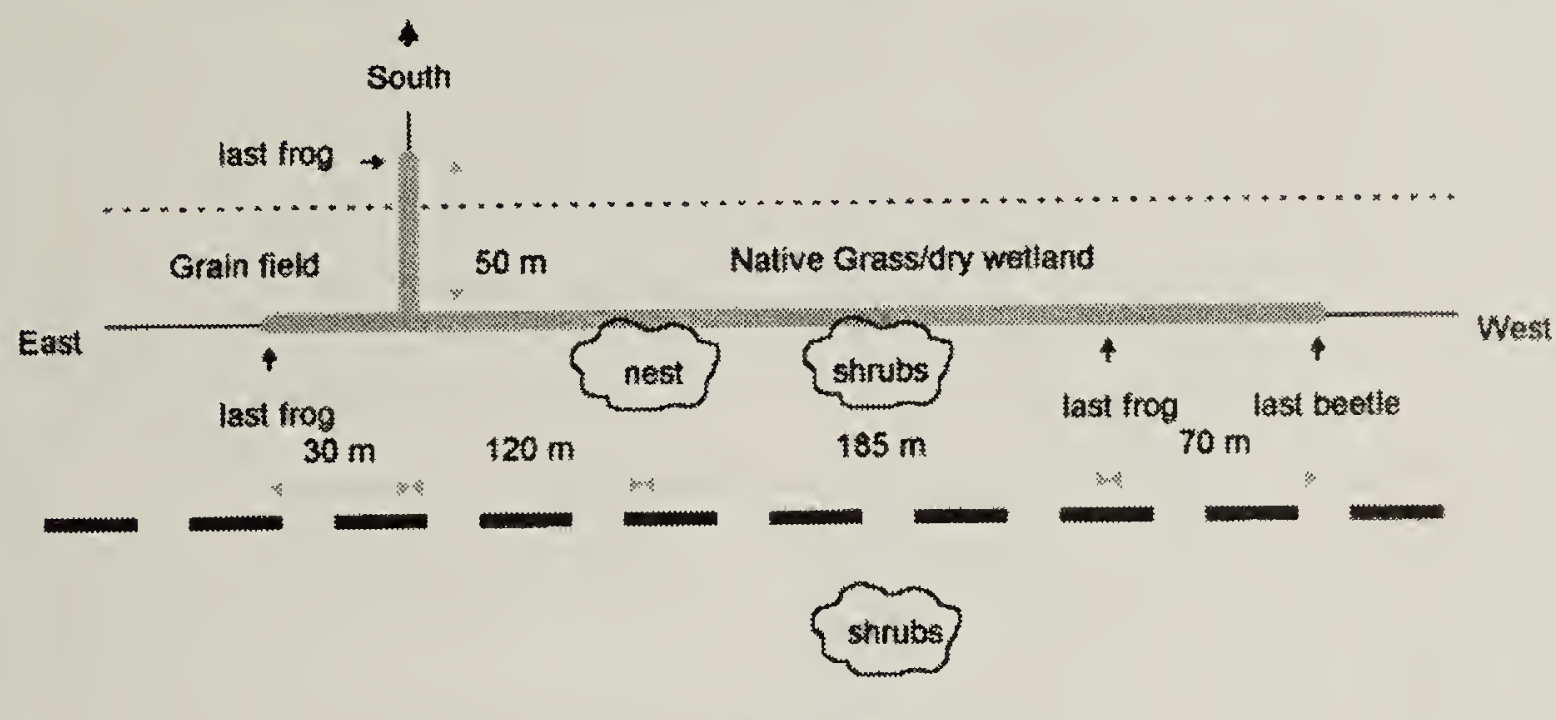

Grain field

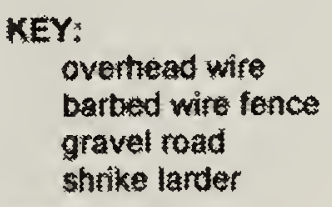

commonly found in Caragana (Caragana arborescens) hedges. The nearest Caragana was in a farm yard $730 \mathrm{~m}$ west of the nest or about $540 \mathrm{~m}$ west of the majority of the impaled beetles.

Our last visit was made to the site on August 8, 2000. We searched all the barbed wire for impaled prey items and discovered that all items were gone except for three frogs. The frogs also were gone from the thorns in the buffaloberry nest bush. The only shrike observed in the vicinity was a single fledged young hunting from a perch on a brush pile about 550 metres west of the nest site. The young shrike was observed catching and eating a Twostriped Grasshopper (Melanoplus bivittatus). The shrike dove off its perch, landed next to the brush pile, captured the grasshopper and flew back to its perch. The shrike held the grasshopper horizontally in its bill, then rotated it 90 degrees and swallowed it whole, head first. The bird also was observed chasing a white butterfly, but failed to catch it. No other shrikes were observed in the vicinity.

\section{Discussion}

Yosef lists arthropods and amphibians as prey items of the Loggerhead Shrike in addition to small to medium-sized reptiles, small mammals and birds. ${ }^{4}$ Several different frogs and toads have been recorded in shrike larders including: Blanchard's Cricket Frog (Ascris crepitans) and Plains Leopard Frog (Rana blairi) ${ }^{3}$, Pickerel Frog (Rana palustris) ${ }^{2}$, Green Tree Frog (Hyla cinerea), Squirrel Frog (Hyla squirella), Southern Leopard Frog (Rana spenocephala) and Eastern Narrow Mouthed Toad (Gastrophyne carolinensis). ${ }^{5}$

The high incidence of frogs in this larder is likely a function of hunting perch choice of the adult shrikes. The overhead wire that one of the adults was initially observed on passed over the edge of a dry wetland. From this vantage 


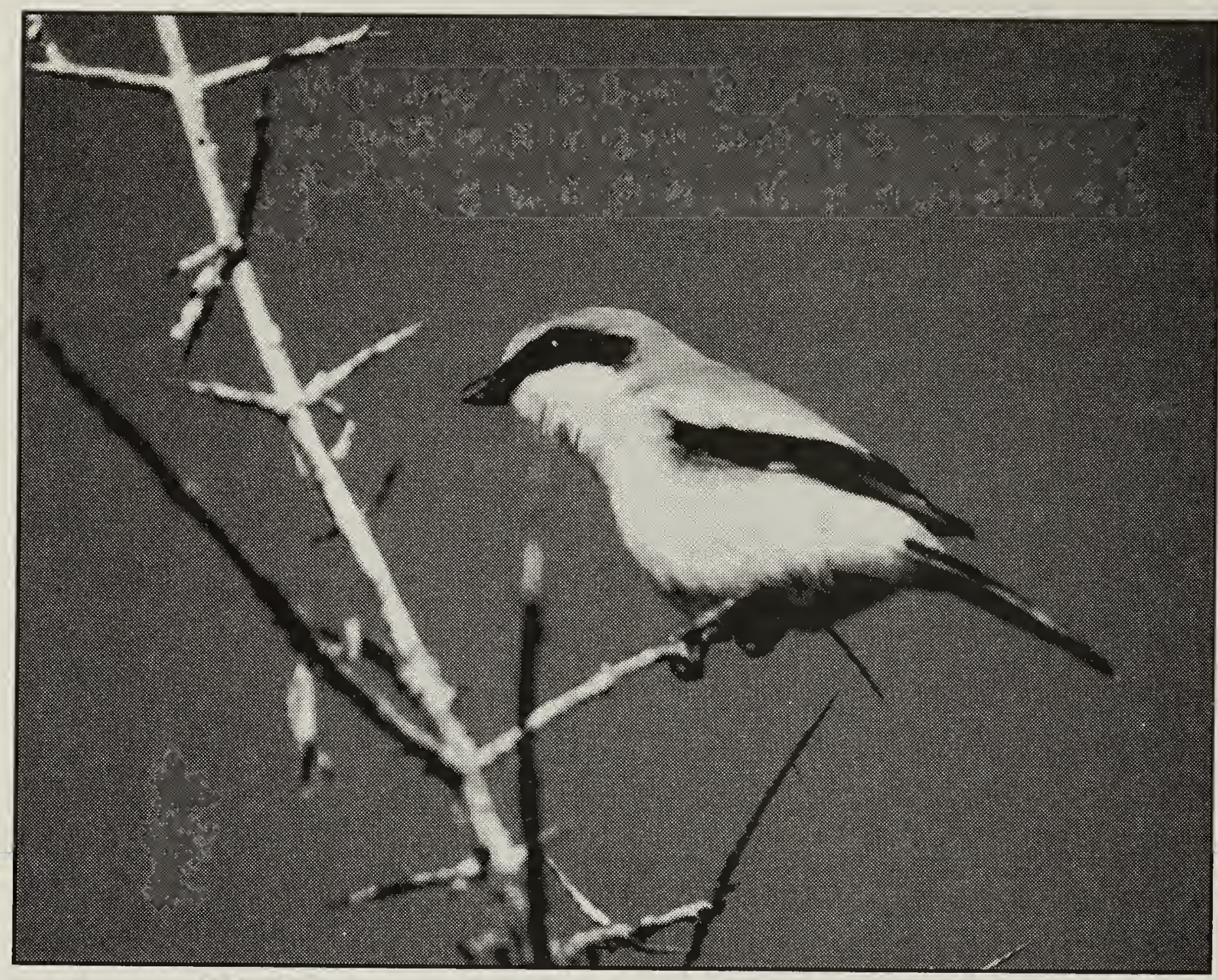

point, a shrike could easily observe frogs moving along the margin of the wetland below.

The Eastern Narrow Mouthed Toad is interesting in that it has a chemical defense system that makes it foul tasting to predators. Shrikes have been known to impale other prey items with chemical defenses such as Monarch Butterfly and Lubber Grasshoppers (Romalea guttata). ${ }^{7}$ In the wild when shrikes have been observed feeding on Lubber Grasshoppers, which have poison glands in their thorax, the grasshoppers were captured and impaled immediately. ${ }^{7}$ Grasshoppers were aged for 24-48 hours while the toxin degraded, allowing the shrikes to eat the grasshoppers without an adverse reaction. Shrikes readily ate the head and abdomen, but often discarded the poisoned thorax.
In the larder near Kenaston, we discovered prey items that exhibit a means of chemical defense. The Nuttall's Blister Beetle, of which there were a total of 20 impaled on the barbs of the fence, utilizes cantharidin, a bitter, blister forming chemical, to protect it from predators. In this instance, impaled blister beetles were all gone by 8 August and presumably eaten. Fresh blister beetles were not eaten in feeding trials involving captive shrikes ${ }^{8}$, however, in this larder, it appears that blister beetles that had been allowed to cure while cached were utilized in some fashion. Since we made no direct observations of shrikes feeding on blister beetles from the cache, further observation is needed for confirmation.

There are a number of theories as to the purpose of the larder or cache. Applegate observed a female shrike 
raiding the larder to feed her nestlings. ${ }^{1}$ In addition, while she brooded the nestlings at night, the male raided the larder to feed the brooding female. Yosef and Pinshow found that the size of the larder is used to attract potential mates and is related to the reproductive success of pairs. ${ }^{6}$ Since the larder we found appeared fully stocked after the young had fledged, it is conceivable that Loggerhead Shrike larders may also be used to provide supplemental food for the young while they are learning to hunt on their own.

\section{Acknowledgments}

We thank Andy Didiuk and Cedric Gillott for identification of prey items and Phil Taylor for reviewing an earlier draft of this note.

1. Applegate, R.D. 1977. Possible ecological role of food caches of Loggerhead Shrike. Auk 94:392-392.

2. Bent, A.C. 1950. Life Histories of North American Wagtails, Shrikes, Vireos and Their Allies. Dover Publications Inc. New York.

3. Tyler. J.D. 1991. Vertebrate prey of the Loggerhead Shrike in Oklahoma.
Proceedings of the Oklahoma Academy of Science 71:17-20.

4. Yosef, R. 1996. Loggerhead Shrike (Lanius ludovicianus). In The Birds of North America, No. 231. (A. Poole and F. Gill, eds.). The Academy of Natural Sciences, Philadelphia, and The American Ornithologists' Union, Washington, D.C.

5. Yosef, R. and T.C. Grubb. 1993. Effect of vegetation height on hunting behavior and diet of Loggerhead Shrikes. Condor 95:127-131.

6. Yosef, R. and B. Pinshow. 1989. Cache size in shrikes influences female mate choice and reproductive success. Auk 106:418-421.

7. Yosef, R.J. and D.W. Whitman. 1992. Predator exaptations and defensive adaptations in evolutionary balance: no defense is perfect. Evol. Ecol. 6:527536.

8. Yosef, R.J, J.E. Carrel, and F.E. Eisner. 1996. Contrasting reactions of Loggerhead Shrike to two types of chemically defended insect prey. Journal of Chemical Ecology 22:173-181.

\section{1}

\section{LONG-EARED OWL ABUNDANCE NEAR SASKATOON IN 2000}

MARTEN J. STOFFEL, RR\#4, Box 183, Saskatoon, SK S7K $3 J 7$

Year 2000 was "the year of the Longeared Owl." A survey of raptors in a fivemile wide strip that extends eight miles from the north end of Saskatoon to Martensville and Warman (40 square miles or 182 square $\mathrm{km}$ ) yielded 34 breeding pairs of Long-eared Owls. Another two pairs were present immediately outside this area, practically "across the road." This number of 